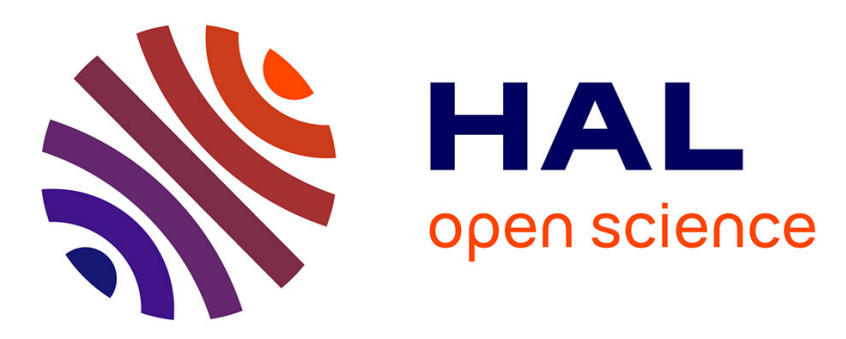

\title{
Evolution of traditional agroforestry landscapes and development of invasive species: lessons from the Pyrenees (France)
}

Sylvie Guillerme, Hugues Barcet, Nicolas de Munnik, Eric Maire, Claire Marais-Sicre

\section{To cite this version:}

Sylvie Guillerme, Hugues Barcet, Nicolas de Munnik, Eric Maire, Claire Marais-Sicre. Evolution of traditional agroforestry landscapes and development of invasive species: lessons from the Pyrenees (France). Sustainability Science, 2020, 15 (6), pp.1285-1299. 10.1007/s11625-020-00847-1 . hal03070831

\section{HAL Id: hal-03070831 \\ https://hal.science/hal-03070831}

Submitted on 16 Dec 2020

HAL is a multi-disciplinary open access archive for the deposit and dissemination of scientific research documents, whether they are published or not. The documents may come from teaching and research institutions in France or abroad, or from public or private research centers.
L'archive ouverte pluridisciplinaire HAL, est destinée au dépôt et à la diffusion de documents scientifiques de niveau recherche, publiés ou non, émanant des établissements d'enseignement et de recherche français ou étrangers, des laboratoires publics ou privés. 
Guillerme, S., Barcet, H., de Munnik, N. et al. Evolution of traditional agroforestry landscapes and development of invasive species: lessons from the Pyrenees (France). Sustain Sci 15, 1285-1299 (2020). https://doi.org/10.1007/s11625-020-00847-1

\title{
Evolution of traditional agroforestry landscapes and development of invasive species: lessons from the Pyrenees (France)
}

\author{
Guillerme Sylvie ${ }^{1}$, Barcet Hugues ${ }^{1}$, de Munnik Nicolas ${ }^{1}$, Maire Eric ${ }^{1}$, Marais-Sicre \\ Claire $^{2}$ \\ ${ }^{1}$ CNRS/Université Jean-Jaurès, UMR 5602, Laboratoire GEODE, 31000 Toulouse, \\ France \\ ${ }^{2}$ Université Paul Sabatier/CNES/CNRS/INRA/IRD/UPS, UMR 5126, Laboratoire \\ CESBIO, 31000 Toulouse, France
}

Corresponding author: sylvie.guillerme@univ-tlse2.fr , Tel. (0033) 6039475 04, fax (0033) 561504275

\begin{abstract}
The term agroforestry covers practices that are promoted to maintain or even enhance biodiversity. However, the relationship between agroforestry and invasive species is rarely addressed, even though the spread of such species is an important issue, not only ecologically but also economically and socially. Over the past few decades, humans have greatly accelerated the process of biological invasions, to such an extent that they are now recognized as the second cause of rapid decline in biodiversity.

In France (as in other parts in Europe) abandonment of agricultural land in remote areas is a major problem having socio-economic, landscape and environmental implications. The objective of the research presented here was to find a method for studying the relationship between traditional agroforestry systems and invasive species, despite a lack of available data. We investigated the evolution of a traditional agroforestry system in the Pyrenean foothills, where invasive species are abundant, by implementing two complementary methods: i/ interviews highlighting the local stakeholders' perception of landscape evolution, invasive species and the challenges they represent for the local traditional agroforestry landscapes, and ii/ detailed mapping of an area occupied by invasive plants, by means of very high resolution spatial technologies using UAV's and aerial photography.

The results show that invasive species have spread in relation with the abandonment of agricultural land, which has also led to "landscape closure" by the encroachment of natural afforestation. They also underline the difficulty of assessing the spread of invasive species. This situation is of major importance in terms of land-use planning, as the various stakeholders have different perceptions of the problem, and it raises questions about the sustainability of practices and territories.
\end{abstract}

Keywords

Agroforestry, Land abandonment, Landscape dynamics, Invasive Alien Species (IAS), Perceptions, Place attachment, UAV Technology 


\section{Introduction}

Agroforestry systems, based on tree components, are usually viewed as sustainable land use options (Rigueiro-Rodríguez et al. 2009; McAdam et al. 2009; Jose 2012), offering the potential to solve important ecological and biodiversity problems while enabling the production of food, wood products and/or fodder for animals at the same time (Nerlich and al. 2013). The term "High Nature Value Farming" (Baldock et al. 1996) reflects the advantages offered by traditional agroforestry systems as well as the valued semi-natural habitats that are associated with them, the majority of which are found in remote areas under extensive land use.

While the pressure on agricultural land is increasing on a global scale in terms of availability, the dynamics of European landscapes is characterized by contrasting trends, which have been particularly marked since the end of World War II: i/ the disappearance of tree elements in areas most suitable for large-scale cultivation and ii/ the developing encroachment of natural forest where farming practices (particularly those linked to livestock) have been abandoned or are in decline.

Thus, although trees represent a structuring element of many rural landscapes associated with traditional forms of agroforestry, in the first case, the pursuit of increased productivity has led to a specialization of modern agricultural or livestock systems, while the second has led to the non-use of trees. Both trends have resulted in a decline in the use and value of trees outside forests (Guillerme et al. 2009).

Agricultural land abandonment is one of the main processes of change in land use in Europe (Keenleyside et al. 2010; van der Zanden et al. 2017; Vinogradovs et al. 2018). It leads to a homogenization of landscapes and has been increasing since the 1950s (Cramer et al. 2008). Land abandonment is a complex and multidimensional process (Munroe et al. 2013) that causes changes in rural livelihoods and agricultural practices. It has become a major concern due to its environmental, socio-economic and landscape dimensions (Lasanta et al. 2017). It also constitutes an important challenge in terms of sustainability and land use planning, especially in marginal agricultural areas and remote and/or mountainous zones.

Agricultural land abandonment and rural depopulation provide a special opportunity for cultivated alien plants (Pandi et al. 2014). Species that are nonnative and non-invasive can become invasive as habitats and dispersers change. This combination of changes can cause rapid increase of a non-native species, allowing it to become invasive (Lenda et al. 2012).

Invasive species have become an issue all over the world, on all types of land (agricultural or natural). Over the past few decades, humans have greatly accelerated the process of biological invasions, to the point where they are now recognized as the second cause of accelerated decline in biodiversity (Simberloff and Rejmánek 2011; Lévêque et al. 2012). The impact of invasive plants on natural vegetation is currently being widely studied (Powel et al. 2011; Barney 2016; McCary et al 2016). It has been shown that, when non-native plants invade an environment, they are capable of outcompeting native plant species through either 
direct (Daehler 2003) or indirect competition (Tanner and Gange 2013). Invasive weeds are an increasing problem because they are difficult and costly to control.

One of the difficulties is that, even when an invasion is territorially assessed, it remains very complex to quantify, and its spatial extension is hard to assess. Although IAS are widely explored by research in the ecological sciences, knowledge of their spatial dynamics and characterization remains complicated (Michez et al. 2016), which is a barrier to their management. Since the 1990s, remote sensing has been used to monitor and map the first outbreaks (Huang and Asner 2009; GroßeStoltenberg et al. 2016; Alvarez-Taboada et al. 2017), to identify optimal periods for applying mitigation treatments (Wallace et al. 2016), to model invasion risks (Huang et al. 2009; Bradley 2014) or to monitor the effectiveness of management measures (West et al. 2017).

High spatial resolution imagery (about $10 \mathrm{~m}$ resolution) has been widely used to detect and monitor invasive plants but it is only effective when plots and/or stands occupy a large area (Wallace et al. 2016) and remains unsatisfactory for detecting alien plants in the ecotone or for mapping a small area in detail (Alvarez-Taboada et al. 2017). However, the evolution of technologies, and of drones in particular, is removing a number of scientific barriers by allowing very high spatial resolution $(\sim 10 \mathrm{~cm})$ acquisition.

During the last decade, in which the advent of these technologies has been particularly marked, several studies have found effective approaches for identifying invasive plants (Bradley 2014; Alvarez-Taboada et al. 2017). However, the difficulty of measuring the spatial expansion of these species accurately, especially in a treecovered environment, has also been highlighted (Dash et al. 2019).

Various studies (Arim et al. 2006; Davidson et al. 2015; Akodéwou et al. 2019) have been conducted with the aim of understanding the spatial dynamics of invasive species but recent decades have seen a marked shift in focus from topics addressing the mechanisms of invasions and the underlying process towards more a complex perception of invasions, where the socioeconomic and social perspective on invasive species is recognized as increasingly important (Pysek 2017; Shackleton et al. 2019).

Many non-native trees (NNT) have been planted worldwide in agroforestry systems for timber, fodder, erosion control, shade and aesthetics, and some of them are now qualified as invasive (Richardson and Rejmánek 2011). Some research projects conducted in Brazil (Ramos et al. 2015; Cordeiro et al. 2018) have shown that agroforestry systems provide less favourable habitats for exotic species, filtering them from the understory, but the mechanisms that may select against exotic species in agroforestry remain unknown (Ramos et al. 2015) and data are lacking in other places, including temperate environments.

The relationship between agroforestry and invasive plant species is rarely addressed. Yet the spread of invasive species is an important issue, not only ecologically but also economically and socially. The objective of the present work was to study the evolution of the traditional agroforestry system in the Oussouet valley (foothills of the Pyrenees mountains in France) where invasive plant species are abundant. Here (as in other parts in Europe), the abandonment of agricultural activities is a major problem, having environmental, socio-economic and landscape 
implications. The paper considers the landscape dynamics as well as the diverse perceptions expressed by the stakeholders we interviewed concerning the invasive species that have spread. The issue of mapping the invasive species is then addressed. Finally the link with sustainable development is discussed.

\section{Materials and methods}

The approach used to address these issues integrates social geography and spatial sciences, and provides an analytical framework for understanding how territorial and agrosystem changes interact with the dynamics of social systems.

\section{Study area}

The area surveyed in France is located in the Oussouet valley, which is representative of local traditional agroforestry landscapes based on a combination of grazing lands, trees, and livestock, located in the Pyrenees mountains in the south of France (Fig.1A). This sector of the Hautes-Pyrénées department is on the fringe of the Pyrenees National Park and near the town of Bagnères-de-Bigorre. It is a mid-mountain area with a climate having oceanic influences. Rainfall is high due to the location in the foothills of the mountain range. The altitude and climatic conditions in this area result in two types of landscapes characterized by specific vegetation:

- $\mathrm{i} /$ in the hillside level $(<800-1000 \mathrm{~m})$, where precipitation is normally high, habitats are composed of meadows and stream banks in the valley bottoms. On the slopes, deciduous forest and thickets dominated by beech [Fagus sylvatica L.) cover most areas, but there are also some grasslands and some bracken fields (extensive, often closed, communities of the large fern Pteridium aquilinum L. [Devillers et al. 1991]). - ii/ in the mountainous level $(>800-1000 \mathrm{~m})$, which is cool and very humid with strong cloud cover, the vegetation consists of deciduous and coniferous forests, bracken fields and recolonizing thickets (mainly of holly [Ilex aquifolium $\underline{L}$ ] and willow trees [Salix spp.]).

This area - where the population is gradually decreasing - is characterized by three main types of human activities, based upon the exploitation of the natural resources of this rural mid-mountain region (data provided by the municipal authorities): i/ pastoralism (associated with bovine, sheep, goat and horse breeding); ii/ forestry, which is quite an important activity in numerous areas of coniferous and beech forest, mainly in the mountain area; and iii/ slate mining, which used to be the particularity of the Oussouet valley. The municipality of Labassère (Fig. 1A) is situated on an outcrop of high-quality slate schist and three slate quarries are present in the area but all have ceased mining operations. The region is also characterized by a strong neo-rural population and numerous second homes.

As far as vegetation is concerned, this very rural and pastoral valley ultimately presents the paradox of benefiting from high specific biodiversity with a diversified flora (Corriol 2016) while, at the same time, being a place where many invasive alien species have spread (Fontaine et al. 2014). 


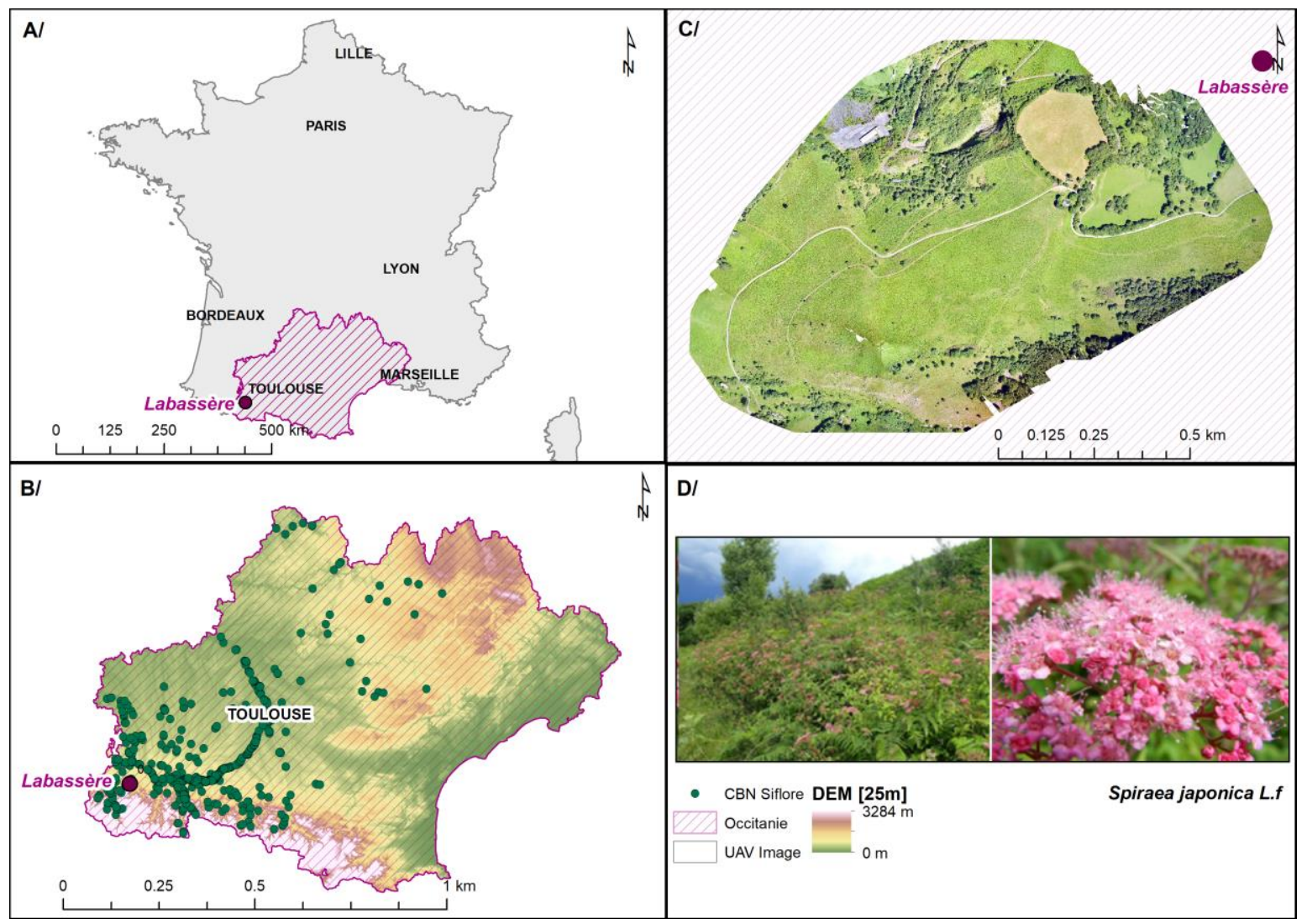

Fig. 1. Location of the study area in France (A), the presence of Spiraea japonica in the Occitania region (B) and the survey site for UAV capture (C) of Spiraea japonica (D) [The presence of the plants was mapped from the Siflore database (National Botanical Conservatory - France)]

\section{Survey method}

Practices and perceptions were placed in the spatial and temporal context of the territory, which was considered as a set of elements in dynamic interaction. It also corresponds to a functional spatial entity, with landscapes reflecting different environmental and anthropogenic processes. People's perceptions and practices concerning the evolution of the agroforestry landscape and invasive species were studied through qualitative interviews, and assessed by a botanical survey.

A qualitative approach to agroforestry and invasive (or qualified as such) species present in the study area was sought. We wished to adopt an "intermediate" posture between the "theoretical saturation" and "qualitative tradition" described by Savoie-Zajc (2009), in order to define the corpus of semi-directed interviews. In qualitative research based on an ethno-phenomenological and discursive approach, several authors refer to a maximum number of about ten interviews. In the aim of remaining as close as possible to the experience of those acting "in the field" (Retaillé, 2010) and capturing a broader diversity of perceptions, we finally conducted 18 open or semi-directive interviews. The local stakeholders were randomly selected, in order to triangulate data. We interviewed people of the 
valley having diverse activities, including livestock farmers, local elected officials, teachers, actors in the biodiversity field, the slate mining activity, and residents (formerly settled and neo-rural residents (Table 1 ).

\begin{tabular}{lc}
\hline \multicolumn{1}{c}{ Main activity } & $\begin{array}{c}\text { Number of } \\
\text { interviewees }\end{array}$ \\
\hline Livestock farmer (in activity) & 3 \\
Livestock farmer (retired) & 3 \\
Elected official & 2 \\
Retired teacher & 2 \\
Actor in the environment or biodiversity field & 2 \\
Slate mine manager & 1 \\
Resident* & 2 \\
Neo-rural resident** & 3 \\
\hline \multicolumn{2}{c}{ Total } \\
${ }^{*}$ Formerly settled residents of the valley & 18 \\
${ }^{* *}$ New settlers having no previous connection with the valley &
\end{tabular}

Table 1. Description of the sample of interviewees in terms of their main activity (Note: in case of multiple activities the main one considered during the interview is mentioned)

The interviews were conducted in the field and/or in the homes of the respondents, in a conversational mode rather than following a strict pre-defined list of questions. All interviews started with broad questions on the interviewee's professional and associative activities, and life history in connection with the valley. It was followed by questions about the experience of the respondents regarding the valley, the evolution of landscapes and activities, biodiversity and their perception of invasive species. An interview guide with the main themes and questions addressed during the interviews was used as a guideline but enriched by additional questions in accordance with each person's profile and responses. The agroforestry concept was never explicitly used in the interviews, but was a conceptual lens to analyse the transcripts. In contrast, the term invasive species was deliberately used in order to understand the way respondents understood this expression, and what they personally considered as "invasive".

The interviews were recorded (with the oral consent of the respondents), transcribed in full, and manually coded using a thematic coding. A regressive approach was used to understand the processes of evolution of this landscape, and the associated agrarian practices and perceptions, in a spatial and temporal dimension. The objective was to start from the stakeholders' experience in order to reconstruct "the structural aspect of the situation or the intervention area considered in terms of stakeholders, challenges, interests [...] that give meaning and coherence to this life experience" (Friedberg 1993). In identifying these representation systems and local practices, we sought to seize the perceptions of the landscape's evolution and the issues related to it, and the meaning that the stakeholders assigned to their practices and to the events they may have witnessed (Blanchet and Gotman 2010). 
Hence, the results of the qualitative analysis of the interviews focus on i/ the evolution of the landscape (in order to describe the structure and history of the agroforestry landscapes of the valley from the beginning of the century to the present day and to understand the context in which the invasive species have spread), ii/ the factors perceived as favouring invasiveness, and iii/ a typology of perceptions about invasive species To achieve more detailed insight into the spread of IAS, we also carried out a mapping process that was complementary to this social survey.

\section{Mapping method}

In order to characterize the spatial dimension of invasive species, a fine (metre scale) mapping of a pastoral area of the valley (upstream sector of the Oussouet valley - Labassere, Fig.1C) was carried out. The species targeted was Spiraea japonica (Fig.1D), which was easy to identify for the purpose of testing the method.

The areas occupied by these invasive plants were assessed by means of very high spatial resolution drone-based technologies (UAV's - Unmanned Aerial Vehicles) and aerial photography. However, this method could not be implemented everywhere (places with heavy tree cover were not suitable for UAV investigation, except with LIDAR sensors). Aerial photography helped to understand the evolution of a landscape over the last two decades, while UAV images showed the spatial extent and recent progression of Spiraea japonica over the last 2 years and attested to the evolution of this pastoral area of the valley.

These supervised classifications, based on the random forest algorithm developed by Breiman in 2001, enabled the elements of a dataset to be quickly labelled from a set of previously known examples. To generate the classification mode used with ortho-photographs, we took the same data set to provide examples for all years. The data were collected in the field in 2018, photo-interpreted on images from 2001 and visually verified for all years.

For the classification generated from the drone images, we used the spectral bands provided by the sensor (G-R-NIR-RE), to which we added various indices highlighting vegetation, soil or the chlorophyll content of plants (NDVI [Trucker, 1979], RVI [Jordan, 1969], DVI [Richardson and Weigand 1977], TSAVI [Baret et al. 1989], MTVI 2 [Haboudane et al. 2004]) that enhanced the detection of relevant objects. The classification was also based on data collected during field investigations and/or photo-interpreted on the RGB drone image. These data were divided into two independent sets, $60 \%$ of the data being used for training and $40 \%$ for validation. The findings from this method are presented in the last part of the results section.

\section{Results}

An age-old agroforestry landscape: a consensual description of the evolution of landscapes and practices

A key initial result emerging from the interviews was the existence of a consensual description of the evolution of the landscapes and activities in the valley by the respondents who had always lived there, or had heard about it (from neighbours or relatives) if they were too young to have had their own experience or if they 
were recently settled. Only two persons (neo-rural residents) were unable to speak much about the past of the valley. Not surprisingly, the livestock farmers provided a multitude of details and narratives. The main features evoked concerning the practices and the evolution of the landscapes are given below.

Hedges were a key element of the landscapes, with fenced fields, hay meadows and grazing meadows. Trees were fundamental in the lives of the families, not only for the timber, firewood and fruit they provided, but also for the protection they furnished for animals and the soils. Livestock farmers qualified trees as essential in the lives of the families. However, they also pointed out that open, extensive meadows found at higher altitudes were crucial for the animals as well. Livestock rearing and traditional cultivation methods described by the interviewees created a landscape mosaic with various species-rich grasslands. Such landscapes were the result of labour-intensive agricultural land-use.

The farming system of the valley was based on a strong predominance of smallscale livestock farms (cattle, sheep and goats, linked with cattle breeding) when rearing animals was a major activity. This was a prosperous activity for the valley's livestock farmers grew corn for the family, the poultry and other animals. No-one in this valley lived from crop farming alone as yields were low. Peasants used to go onto communal grazing lands to collect bracken to use as bedding for animals. Most of the older stakeholders and farmers insisted on the presence of a large rural population involved in agricultural activities in the valley.

This age-old agroforestry that shaped the landscapes of the area was also linked to the economic activity of slate quarries. The availability of what the respondents used to call "high-quality slate schist" was responsible for the presence of three slate quarries in the valley. Their activity was linked with the agricultural decline that started 70 years ago. The population began to abandon unprofitable agriculture to work in the slate quarries, which were hiring manpower. All the respondents who knew this period were unanimous in stating that at least one member of each family was employed there in order to improve the family income, and managed to combine this job with the farming activities.

It was underlined that the valley has later underwent significant depopulation and a decline in traditional farming and agroforestry practices. Many farmers have left the valley and their activity to look for work in the cities, so the agricultural land of the valley has gradually became abandoned. The depopulation of the valley was reported by various stakeholders (and could also be assessed from data provided by the village), some of them specifying that they had witnessed the disappearance of one third of its farmers in the last 20 years. Some farmers remain, but have not been able to maintain the agroforestry structure. Now they only grow fodder crops. Livestock breeding is also declining, even though most of the remaining farmers still continue some pastoral activities. However it was mentioned that the herds that can be seen in the valley no longer belong to the valley's breeders only. Hence the farmers are finding the pastoral activity overly constraining and are withdrawing from it.

Interviews revealed that nowadays, half the inhabitants of the valley are said not to be farmers. While many farming families have gradually left in the past two decades, neo-rural residents have recently been settling in the valley and buying some of the old farms. These new settlers are attracted by the proximity of the 
town where they work, the lower price of land, and the landscapes. They are mostly people who have come to live in the area but have other professional activities in the nearby town of Bagnères-de-Bigorre or its surroundings.

\section{A decline of the agroforestry complex: factors perceived as favouring invasiveness}

The narrative data collected through the interviews about the evolution of landscapes and practices highlighted what species were considered as invasive by the respondents and the factors behind their spreading in the valley. Two types of drivers were identified: the first is linked with the farming activity, and the second with the slate mining.

i/ The set of explanations given first and foremost concerned the gradual abandonment of agricultural activity in connection with the general depopulation of the valley. Hence only the few farmers remaining in the valley still help to maintain the landscape through pastoralism, and the presence of trees in the landscapes bears witness to their past use in agroforestry. As the hedges are no longer being exploited or managed, many trees (such as ash [Fraxinus excelsior L.] or birch [Betula L.], the tree species that were most easily named by the respondents) were pointed out as having grown spontaneously from hedgerows. Here, the feeling of invasiveness is expressed to qualify the development of this vegetation which has gradually colonized the abandoned fields and meadows, contributing to a "landscape closure" by encroachment of natural afforestation. A young livestock breeder said "I like a valley when it's clean and tidy. You say to yourself, "Here, they worked". Arriving in a valley like ours, which is wooded everywhere, you say to yourself, "But there are no farmers here, what's going on? ").

Questions about the family history and activities of the interviewees showed that many farming families have left the valley to settle and seek work in cities. In the majority of the farming families who have decided to stay in the valley, at least one member has been compelled to develop a second activity in order to supplement their income because neither the farm nor the quarries can ensure a livelihood for their families, as mentioned earlier. And this reduces the time they can invest in maintaining the landscapes, a situation again favouring the spread of unwanted vegetation.

On the one hand, the number of people able (and willing) to maintain the landscape as it was in the past is decreasing and, on the other hand, potential young farmers are discouraged from settling here (by many obstacles, such as high investment costs). In consequence new establishments are rare.

The land left vacant following the cessation of agricultural activity has mainly been bought or rented by farmers from outside the valley. The local farmers who mentioned that point were complaining that these non-resident farmers do not have the same practices (the practices of the newcomers being considered more extensive and failing to maintain the landscape of the valley as finely as they themselves do).

The last correlated argument expressed to explain the spread of invasive vegetation is the lack of mechanization possibilities in this mountainous area: pasture lands cannot be maintained and are gradually being abandoned, part of the reason being because the steep slopes make mechanization impractical.

To sum up this first set of factors, "Landscape changes have occurred because man was no longer there to control nature", as a mayor put it. 
ii/ The second type of explanation for the feeling of invasiveness is linked with the presence of the slate mining quarries. It was mentioned that, in addition to the weakening of agriculture, international competition has put an end to the slate mining activity. The three slate quarries, which had become economically unprofitable in their turn, have gradually closed (two of them 20 years ago and the other 5 years ago). These sites, left abandoned, have been pointed out as the first places to be invaded by Spiraea japonica. Other IAS, such as Reynoutria japonica, Impatiens glandulifera (Fig.2) and Buddleja davidii [note: most interviewees could recognize and show them in the valley, but few were able to name them, either by a scientific or a local name] were also mentioned on the slate quarry sites, but mostly for having invaded the banks of rivers and roads. The consequence of this double dynamics is that woods, brambles (Rubus fruticosus L.), bracken (Pteridium aquilinum $L$.) and the various invasive species have also gradually spread into the abandoned agricultural plots, contributing to a profound change in the landscapes (Figs. 3 and 4).

Most interviewees, especially the elderly, identified the slate quarries as the cradle for the development of the invasive alien species currently present in the valley, through the extensive movement and transport of soil and rock. The subsequent cessation of slate quarry activity left large areas of "disturbed" schist that would then have favoured the installation and dispersal of these species. The spread of IAS to the forest understorey as well as to the agroforestry plots and meadows was facilitated because the vegetation was no longer managed through the agricultural activity. The abandonment of agroforestry practices gradually facilitated IAS invasion in the landscape. However, none of the respondents were able to assess the process and rapidity of the invasion by IAS more precisely.

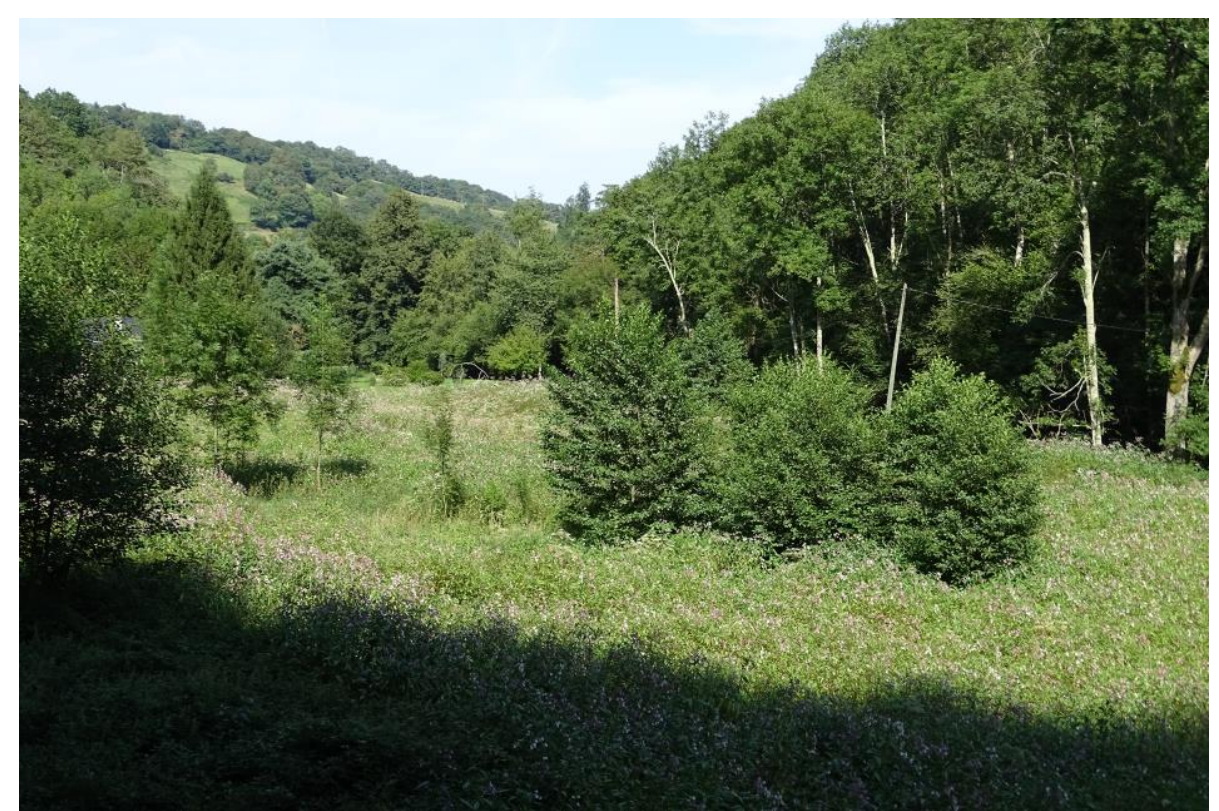

Fig. 2. Abandoned meadow, totally invaded by Impatiens glandulifera and subject to spontaneous reforestation 


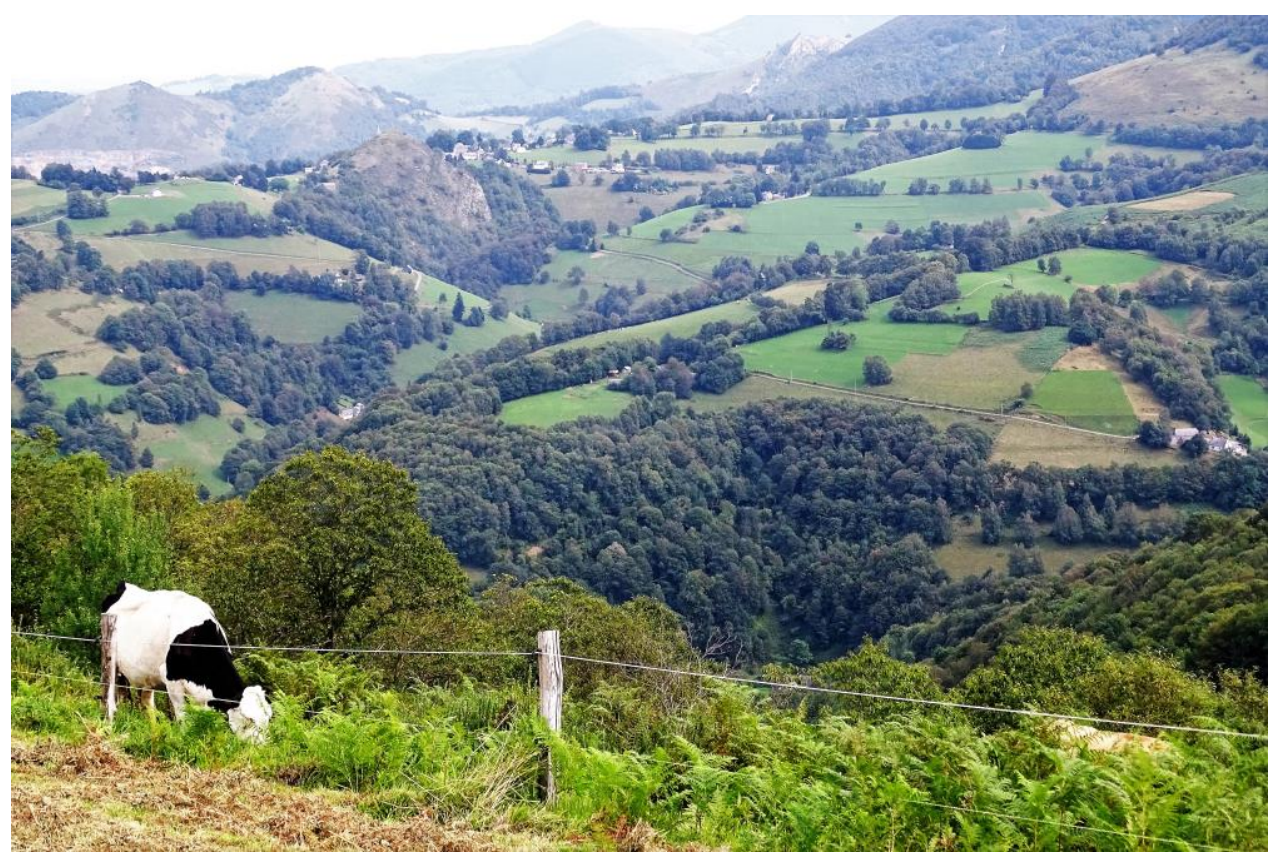

Fig. 3. Traditional agroforestry landscape in a process of abandonment materialized by the expansion of tree components in the fields, and the presence of brambles, bracken and invasive species like Spiraea japonica (Upstream of the Oussouet valley, Labassère, Hautes Pyrénées).

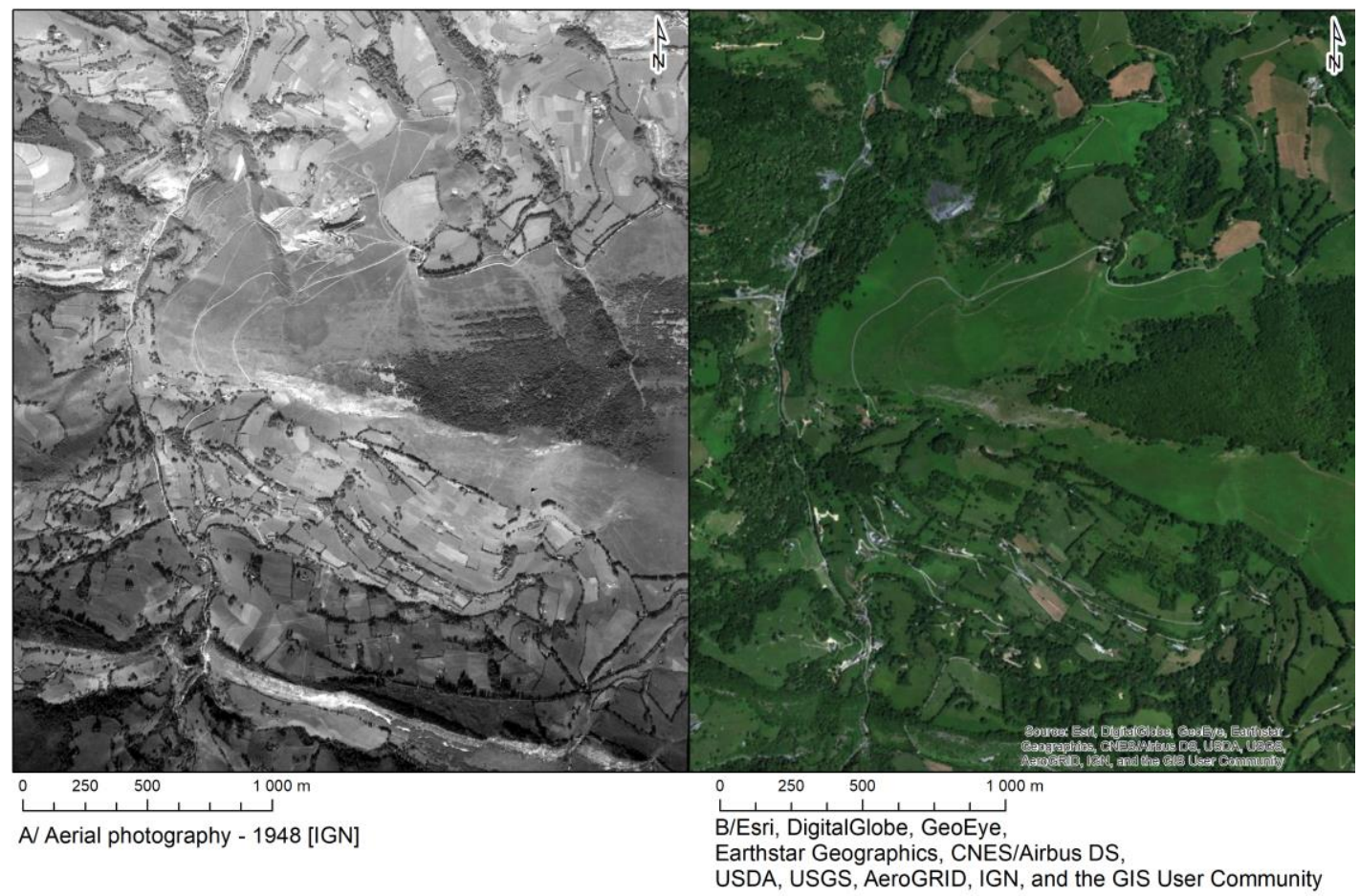

Fig. 4. Evolution of traditional agroforestry landscapes of the Pyrenees (Oussouet valley, Trébons village, France, 1948-2016). The "landscape closure" process by natural afforestation $(B, 2016)$ is a result of the previous agricultural and pastoral activity $(A, 1948)$ that maintained them and avoided their being abandoned, which also favoured overgrowth by various invasive species (IGN aerial images). 
The emergence and development of several IAS in the valley (mainly Reynoutria japonica, Impatiens glandulifera, Buddleja davidii and Spiraea japonica) have contributed to the landscape changes and are seen as an environmental impact of the decline of agriculture. Inductive analysis of qualitative data compiled from interview transcriptions revealed three types of perceptions concerning the IAS in the valley: two took an environmental standpoint (but oriented towards different views), and one was heritage oriented.

\section{i/ Protecting habitats: a conservationist view}

For environmental technicians and managers, and also for ecologists involved in different associations, IAS are considered as species to be eradicated. In their opinion, these species, because they are exotic, should not be there. These people are convinced that the presence of such plants is evidence of a loss of biodiversity. They do not consider IAS as a possible additional component of landscape diversity but as a sign of habitat degradation because, in some spots, IAS dominate the landscapes of the valley. They also fear that their expansion will become uncontrollable. Only a minority is of the opinion that biodiversity also includes these species and that it is sufficient to avoid their excessive spread.

ii/ A so-called "wilderness": aesthetic attractiveness for a neo-rural population Most of the neo-rural people interviewed were not deeply aware of the local history and activities of the valley. One of the motivations of these interviewees, who mostly worked in the nearby town, to settle in this valley was what they termed its "wilderness" quality. For them, the valley looks "wild" due to its forest landscapes. They do not realize that what they call "wilderness" is, in fact, not natural but the result of abandonment of traditional agroforestry practices. It is now the "wild" character conferred by the natural afforestation and the aesthetic value of these IAS (qualified as "colourful and flowery" because Spiraea japonica and Impatiens glandulifera in particular colour the valley pink during summer) that make the valley attractive for some neo-rural people who have decided to settle here, as well as for tourists, who do not know these plants and think that they have always been present in the valley (according to reports).

iii/ What "invasive species" means: the point of view of farmers and the elderly Farmers, on the other hand, do not care much about IAS. However, all the farmers we met stressed that, at present, mostly brambles, but also bracken and various trees, are invading the land very quickly. This factor was stressed as the main argument explaining the spread of a dense vegetal cover: "The vegetation swallows up everything, it's moving at breakneck speed" (an old, long settled resident). Farmers no longer use bracken for animal bedding and, to have good, clean grazing lands, brambles and bracken have to be eradicated, which is difficult and costly. It is essentially brambles and brackens that they consider as invasive species to be eradicated, because they overcome the vegetation of the grazing lands: "It is the brambles that cause the invasion..." (a livestock farmer). They are, in fact, nostalgic for the very well maintained landscapes of the past that testified to agricultural work and a rural way of life that no longer exists "The hedges, they were trimmed, it was neat" (an old farmer). For some of those concerned, brambles, ferns and IAS are simply reminders of the past landscapes to which they were attached and which have now disappeared. For others, they evoke fantasized, wild landscapes. Finally, 
only beekeepers see either brambles or IAS as a resource, since they increase the honey potential of their bees.

\section{The difficulty of mapping invasiveness}

In this section we will consider the results of the mapping method tested. To assess the rapid spread of IAS, mentioned by most of the stakeholders interviewed, and to alleviate the problem of a lack of available data for mapping these species, highlighted by ecologists, we attempted to carry out a fine mapping of an invaded pastoral area of the valley (Fig.1C).

Mapping of IAS has mostly been achieved on a limited scale so far and based on occasional botanical records. The few existing IAS maps have been drawn up on the basis of spot surveys (SI FLORE database) or established by botanical inventory directly in the field but with very limited geographical extents (at best several hundred linear metres) due to the complexity of the work. Yet mapping patterns of invasive plants requires metre or sub-metre spatial resolution to capture the complex nature of the invasion process in order to understand its spatial dynamics. The use of a UAV was therefore preferred. Airborne technology with a drone (UAV) equipped with a multispectral sensor enables a sub-metre land-use map to be produced by remote sensing and, in particular, allows targeted invasive plants to be extracted. It was first used on an open space of grazing land colonized by Spiraea japonica, near one of the old slate quarries.

Detection of invasive species such as Spiraea japonica was especially used to identify the changes in habitats and agroforestry landscapes. The first observations of Spiraea japonica in the selected area (Fig. 1C) were made by the interviewees in the 1950s but, as mentioned above, these plants have been expanding spatially in this area since the early 2000s (Table 2), as also recorded in the SI FLORE data base (http://siflore.fcbn.fr).

\begin{tabular}{lcccc} 
& \multicolumn{3}{c}{ Years } \\
\cline { 2 - 5 } Vegetation type & $\mathbf{2 0 0 1}$ & $\mathbf{2 0 0 6}$ & $\mathbf{2 0 1 0}$ & $\mathbf{2 0 1 3}$ \\
\hline Brambles, bracken and spiraea japonica & 22.07 & 33.09 & 37.39 & 35.03 \\
\hline Spiraea japonica alone & NA & NA & NA & NA \\
\hline
\end{tabular}

Table 2. \% of the total area surveyed

The mapping provides milestones for characterizing "landscape closure" by natural afforestation. The image in Fig. 5B shows the results obtained from an orthorectified aerial image (Fig. 5A) by classifying the bracken and brambles that have accompanied the natural afforestation since 2013. For 2013, we did not have accurate information about the presence of Spiraea japonica. Consequently, due to the absence of previous field data, we were unable to distinguish Spiraea japonica from brambles or bracken and therefore grouped them together in a single class because our botanical surveys show that, in its initial stage, Spirea develops preferentially under the cover of these plants.

The image in Fig. 5D shows the result obtained with a UAV (Fig.5C) for the classification of Spiraea japonica in 2018. The decimetre resolution obtained with 
the UAV provides images of the spatial distribution of the invasive Spiraea japonica plants that are not visible on conventional aerial photos at a resolution of $40 \mathrm{~cm}$. The classification based on the drone image shows $88 \%$ of Spiraea japonica, and $56 \%$ of bracken/brambles. The understanding of this fine spatial dynamics of the Spiraea invasion is still in its initial stages because the survey of this testing area by UAV only started in 2017 . We will continue to conduct drone flights every year to understand its evolution. The advent of UAV technologies will allow us to investigate the dynamics of invasion further via multi-date annual imagery whereas, until recent years, we could rely only on archives of aerial photographs.
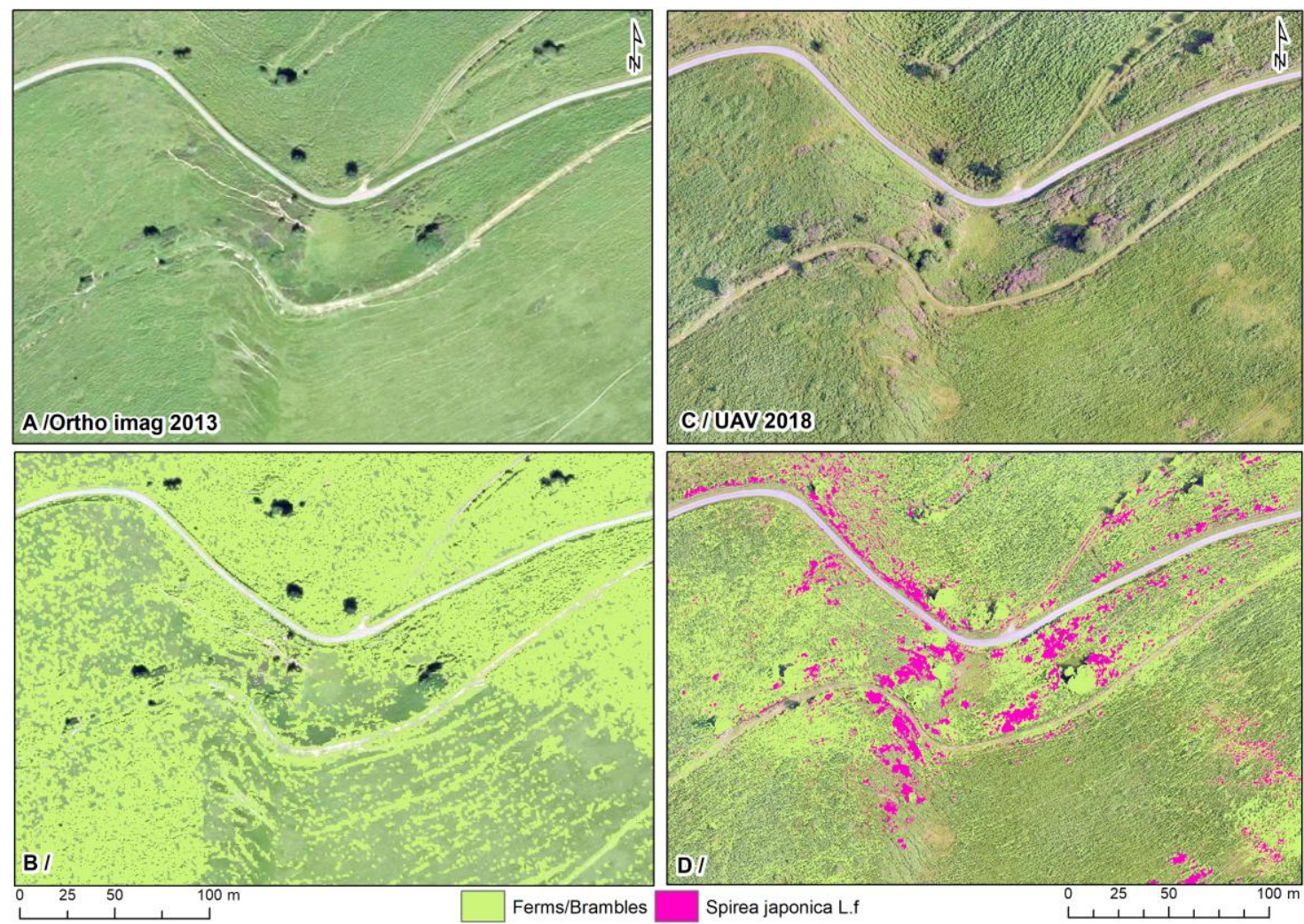

Fig. 5. Images obtained by classification of brambles, bracken and Spiraea japonica in the field area (described in Figure 1): A) Aerial ortho image taken in 2013; B) Detection of bracken/brambles in 2013 superimposed on image A; C) UAV ortho image taken in 2018; D) Detection of bracken, brambles and Spiraea japonica in 2018 superimposed on image C.

\section{Discussion}

Reviews of the literature on land abandonment in European mountains assess its environmental impacts and the decline in traditional farming practices (MacDonald et al. 2000; Antrop 2005). The homogenization of biodiversity as a result of the introduction and migration of species is a global change that profoundly alters the functioning of terrestrial ecosystems (MacDougall and Turkington 2005; Moser et al. 2009). Some authors underline its negative impacts on economic and agricultural activities (Perrings et al. 2002; Paini et al. 2016) and its contribution to the vulnerability of human populations (Andersen et al. 2004). However, the results presented here show that, even if invasive alien plant species are part of the processes of natural afforestation in the study area, they are not perceived 
negatively by all the stakeholders. The presence of invasive species in this valley is a symptom of two interrelated phenomena: land abandonment and anthropogenic disturbance, but mapping the spatial extent of these species and assessing their evolution remains a major challenge for the management of the territories concerned.

\section{The challenge of assessing the evolution of landscapes and ecosystems}

In terms of sustainable development, an approach to invasiveness in agroforestry landscapes requires a precise diagnosis of the spatial extension of invasive plants. This could be obtained by drawing up local maps of IAS distribution in order to compare them with vernacular stakeholders' knowledge. The presence/absence of the species is not enough, even though the inventory of targeted taxa in databases is useful in a first assessment of this environmental issue. It would then be necessary to produce maps reflecting the reality at infra-metre resolution, which could be utilized for discussion in order to confront it with the perceptions of invasive plants voiced by local stakeholders and impacted populations. This question could, hopefully, be answered by the use of multi-date UAV imagery for better monitoring of IAS expansion (Martin et al. 2018).

The success of large-scale control programmes for established invasive species is challenging to evaluate because of spatial variability in expansion rates (Pepin et al. 2019). Mapping the spatial expansion of invasive species is highly strategic for future management but is also a technical challenge in agroforestry conditions since the presence of trees complicates the use of drones for surveys. That is why the challenge for the next few years will be to combine different UAV technologies in order to ensure high-resolution mapping of the invasiveness from the open landscape to the denser tree cover over large areas ( $>200 \mathrm{ha}$ ). This will be made possible by multi-date remote sensing combining two types of UAVs: long-range fixed wing vehicles and multicopters equipped with LIDAR sensors for areas located in tree-covered areas of agroforestry landscapes (Dash et al. 2019).

In the event of natural afforestation and loss of agroforestry structure, such data may provide a better understanding of how invasive species are expanding spatially. This would also be very useful for making appropriate management choices. But this raises the question of the reference state that will be used as a basis for future management, and the time that will elapse between successive recordings, in order to observe the evolution. This will require not only technical means but also human resources to carry out the analyses of the images that will be taken. The budget required will be considerable, especially if the areas to be monitored are large.

From the work described here, we can also affirm that high-resolution mapping will become one of the major challenges in characterizing the processes that allow invasive plants to spread, the aim being to manage them in the best possible way in order to maintain the sustainability of agroforestry landscapes. At present, this approach, which is still in its infancy, has limitations that will have to be overcome if it is to be used over larger areas. The technique is currently very place-specific, whereas a reflection in terms of sustainable landscape management needs to be undertaken on a broader scale. Nevertheless, the results can provide much essential quantitative and qualitative information about IAS that will be very useful 
not only for ecologists but also for decision makers responsible for land-use management. Measuring invasiveness dynamics in the landscapes is therefore essential. But the difficulty of assessing the expansion of invasive plants lies not only in the spatial aspect; ecological analyses are largely influenced by stakeholders' contrasting perceptions of the phenomenon and the species.

Social perceptions of agroforestry and invasive plants: whose sustainability?

Manners of perceiving the landscape can be many and varied. The interviews provided an opportunity to understand the main constraints and potentialities perceived by the participants, and thus to explore the landscapes perceived by individual stakeholders and their close connection with the environment. Research in anthropology as well as in geography (Buijs et al. 2006; Tilley and Cameron-Daum 2017; Soudière 2019) shows how the landscape is constructed by the different perceptions that individuals have of it. Mountain agroforestry systems can play a major role by providing high nature value and maintaining the countryside. But the diversity of stakeholders, who do not necessarily share the same conservation values regarding a territory, is a major issue. Hence approaching this question through IAS is a source of learning in terms of sustainable landscape management.

The interest of any study of invasive alien species obviously concerns the consequences of their expansion, both on the environment and on human activities. However, this subject remains highly controversial in the scientific community itself. Some authors describe these species as "ecological threats" or "harmful" (Gobster 2005; Marbuah et al. 2014; Doherty et al. 2015), while others see actions against these invasive alien species as a form of racism or xenophobia (Simberloff 2003; Lefeuvre 2004; Tassin 2020).

The notion of invasiveness is assessed in a subjective way and we have seen that the value attributed to a species depends on the social perception of the phenomenon. For example no stakeholders interviewed referred to black locust (Robinia pseudoacacia), which is also widespread in the valley. Yet this tree, which was one of the first North American trees introduced into Europe, is ranked among the top plants in Europe having the highest negative impact. In many places it is considered as a part of the rural landscape, economy and culture, having positive aspects such as nitrogen fixation, wide habitat tolerance, fast growth and vigorous vegetative propagation. So the same properties that make Robinia attractive for cultivation are also the source of problems in nature conservation and environmental management (Vitkova et al. 2017).

\section{Agroforestry and alien species management: towards which sustainability?}

The difficulty also lies in the fact that the notion of invasiveness is related to what we know (about the proven - or supposed - threats of these plants, for example, and according to the context) but also to how each stakeholder wants to use the environment. For example, managers of natural areas often encounter public misunderstanding of this problem and it can even become an obstacle to action (Lefeuvre 2004). The time frame for a manager is very narrow because it is easier to act early to be more efficient and minimize costs (Rejmanek and Pitcairn 2002). If it is already difficult for them to act on public spaces, it is even more problematic on private lands, where they have little authority or influence. Thus, abandoned 
plots of land can quickly present a high potential for invasions. This is what we observe in the dynamics of the Oussouet valley. The choice of species introduced into an agroforestry system, the management of the plot, and the species present in the surroundings can constitute sources of invasion when the system is no longer maintained. Many authors point out that IAS can cause significant damage to human activities, not only in ecological terms but also in economic ones (Simberloff 2003) but scientists themselves are not unanimous on this point (Atramentowicz and Barbault 2010; Simberloff et al 2013).

For Udawatta et al. (2019:14) "Agroforestry can promote undesirable species including invasive species if proper measures were not implemented". Based on our results we can also argue that, although agroforestry is seen as a key agrosystem, valuable in terms of sustainability, this is only the case if these landscapes are appropriately maintained, mainly through farming practices. The evolution observed in the Oussouet valley is rich in lessons for many other territories. We have seen that agroforestry landscapes are not immutable, and abandonment of farming practices can be detrimental to them. However, the invasion of these landscapes by exotic species following their abandonment is not necessarily a bad experience for all stakeholders. It is therefore necessary to ask ourselves what sustainable development means: what reference system should we use as a basis? Sustainability as seen by an ecologist will be different from the perception of a farmer or a manager. This consideration is important for decisionmakers and a compromise has to be found between economy, ecology and society, while taking the spatial and temporal dimensions into account (Antrop 2005; Maire et al. 2012; Guillerme et al. 2015).

\section{Conclusion}

In a context of unprecedented environmental crisis, sustainability science has emerged as a new field of research. It aims to create and apply knowledge to support decision-making for more sustainable development (Clark and Dickson 2003; Komiyama and Takeuchi 2006; Lang et al. 2012).

Invasive species represent temporal, spatial and human issues for agroforestry, which is an emblematic response promoting a sustainable approach to landscape management. In the study area of the Oussouet valley, the decline of agroforestry by land-use abandonment has favoured the spread of invasive species, as the landscapes are no longer being maintained. New management strategies are difficult to undertake due to the contrasting perceptions of the different stakeholders as to what is considered as invasive and what has to be protected or eradicated.

Our intention was to carry out an assessment of the sensitive dimension of interviewees' perception of the landscapes and the changes induced by the presence of invasive species by initiating a fine mapping process in order to enrich stakeholders' interviews with precise data. The spatial expansion of IAS observed by UAVs gives very precise results, but does not allow us to understand which territorial dynamics it belongs to (field validations not allowing such global understanding). However, this understanding is possible thanks to detailed surveys conducted among local stakeholders. Conversely, social surveys alone cannot accurately spatialize the extent of IASs, their spatial dispersion or the speed at which they spread. This is possible with high-resolution mapping conducted over 
time. The interdisciplinary approach proposed, combining these two different and complementary methods, represents an asset in understanding what becomes of traditional agroforestry systems when they are left abandoned.

The spread of invasive species is a symptom of such abandonment of practices, and poses challenges in terms of sustainable development. In order to respond to these challenges, it is necessary to consider the diversity of stakeholders with a view to revitalizing agroforestry systems and the multifunctional landscapes associated with them, to get them out of abandonment. This implies assessing the spatial expansion of IAS but also the usefulness - or otherwise - of these invasive plants without qualifying them as threats from the outset.

\section{Acknowledgments}

This research was funded by CNRS through the projects INVASCAPE (GEODE), EI2P (Région Occitanie) and INVAVISION (PEPS TOHMIS CNRS). We are grateful to the Botanical Conservatory for its help, especially to J. Dao, and we warmly thank the villagers of Oussouet.

\section{References}

Akodéwou A, Oszwald J, Akpavi S, Gazull L, Akpagana K, Gond V (2019) Problématique des plantes envahissantes au sud du Togo (Afrique de l'Ouest): apport de l'analyse systémique paysagère et de la télédétection, Biotechnology, Agronomy, Society and Environment, 23(2):88-103

Alvarez-Taboada F, Paredes C, Julia'n-Pelaz J, Alvarez-Taboada F, Paredes C (2017) Mapping of the Invasive Species Hakea sericea Using Unmanned Aerial Vehicle (UAV) and WorldView-2 Imagery and an Object-Oriented Approach, Remote Sensing, 9(9) DOI: 10.3390/rs9090913

Andersen MC, Adams H, Hope B, Powell M (2004) Risk assessment for invasive species. Risk Analysis: An International Journal, 24(4):787-793.

Antrop M, (2005) Why landscapes of the past are important for the future. Landscape Urban Plann. 70(1-2):21-34

Arim M, Abades S, Neill PE, Lima M, Marquet PA (2006) Spread dynamics of invasive species. PNAS, 103(2):374-378

Atramentowicz M, Barbault R (2010) Les invasions biologiques, une question de natures et de sociétés. Editions Quae, Versailles

Baldock D, Beaufoy G, Brouwer F, Godeschalk F (1996) Farming at the margins: Abandonment or Redeployment of Agricultural Land in Europe. Institute for European Environmental Policy, Agricultural Economics Research Institute, London/The Hague

Baret F, Guyot G, Major DJ (1989) TSAVI: A vegetation index which minimizes soil brightness effects on LAI and APAR estimation. In: Proceedings of the $12^{\text {th }}$ Canadian Symposium on Remote Sensing Geoscience and Remote Sensing Symposium, IEEE, pp 1355-1358

Barney JN (2016) Invasive plant management must be driven by a holistic understanding of invader impacts. Applied vegetation science, 19(2):183-184

Blanchet A, Gotman A (2010) L'enquête et ses méthodes, l'entretien. Armand Colin, Paris

Bradley BA (2014) Remote Detection of Invasive Plants: A Review of Spectral, Textural and Phenological Approaches. Biol. Invasions, 16:1411-1425

Breiman L (2001) Random Forests. Machine Learning 45:32-5 
Buijs AE, Pedroli B, Luginbühl Y (2006) From Hiking Through Farmland to Farming in a Leisure Landscape: Changing Social Perceptions of the European Landscape. Landscape Ecol, 21:375-389, https://doi.org/10.1007/s10980-005-5223-2

Clark WC, Dickson NMF (2003) Sustainability science: The emerging research program. Proceedings of the National Academy of Sciences 100(14): 8059-8061

Cordeiro ADAC, Coelho SD, Ramos NC, Meira-Neto JAA (2018) Agroforestry systems reduce invasive species richness and diversity in the surroundings of protected areas. Agroforestry Systems, 92(6):1495-1505

Corriol G (2016) Massif du Monné, vallée de I'Oussouet (Identifiant national : 730011645, ZNIEFF Continentale de type 2). Conservatoire botanique national des Pyrénées et de Midi-Pyrénées, INPN, SPN-MNHN Paris, 29p.

Cramer VA, Hobbs RJ, Standish RJ (2008) What's new about old fields? Land abandonment and ecosystem assembly. Trends in ecology \& evolution 23(2):104-112

Daehler CC (2003) Performance's comparisons of co-occurring native and alien invasive plants: Implications for conservation and restoration. Annu Rev EcolSyst 34:183-211

Dash et al. (2019) Early Detection of Invasive Exotic Trees Using UAV and Manned Aircraft Multispectral and LiDAR Data, Remote Sens. 11:1812. DOI: $10.3390 / \mathrm{rs} 11151812$

Davidson AD, Fusaro AJ, Kashian DR (2015) Using a Novel Spatial Tool to Inform Invasive Species Early Detection and Rapid Response Efforts, Environmental Management, 56:54-65

Doherty TS, Dickman CR, Nimmo DG, Ritchie EG (2015) Multiple threats, or multiplying the threats? Interactions between invasive predators and other ecological disturbances. Biological Conservation 190: 60-68

Fontaine M, Cambecedes J, Barascud Yk, Birlinger A, Tribolet L (2014) Plan régional d'actions: Plantes Exotiques Envahissantes en Midi-Pyrénées 2013-2018. DREAL, Toulouse, 201p.

Friedberg E (1993) Le Pouvoir et La Règle. Seuil, Paris

Gobster PH (2005) Invasive Species as Ecological Threat: Is Restoration an Alternative to Fear-based Resource Management? Ecological Restoration 23(4):261-270

Große-Stoltenberg A, Hellmann C, Werner C, Oldeland J, Thiele J (2016) Evaluation of Continuous VNIR-SWIRSpectra versus Narrowband Hyperspectral Indices to Discriminate the Invasive Acacia longifolia withina Mediterranean Dune Ecosystem. Remote Sens., 8:334

Guillerme S, Alet B, Briane G, Coulon F, Maire E (2009) L'arbre hors forêt en France. Diversité, usages et perspectives, Revue Forestière Française, 5 :543-560

Guillerme S, Jimenez Olivencia Y, Moreno D (2015) Landscapes of Non-woodland Trees; landscapes which reveal the challenges of sustainable development. In Luginbhül Y., Howard P., Terrasson D. (eds) Landscape and sustainable development, the French perspective, Dorchester, Ashgate ed., pp.27-26.

Haboudane D, Miller JR, Pattey E, Zarco-Tejada P, Strachan IB (2004) Hyperspectral vegetation indices and novel algorithms for predicting green LAI of crop canopies: Modeling and validation in the context of precision agriculture. Remote Sensing of Environment 90(3):337-352

Huang C, Asner GP (2009) Applications of Remote Sensing to Alien Invasive Plant Studies, Sensors, 9:4869-4889

Jordan CF (1969) Derivation of leaf-area index from quality of light on the forest floor. Ecology 50(4):663-666 
Jose S (2012) Agroforestry for conserving and enhancing biodiversity. Agrofor. Syst. $85: 1-8$

Keenleyside C, Tucker G, McConville A (2010) Farmland Abandonment in the EU: an Assessment of Trends and Prospects. Institute for European Environmental Policy, London

Komiyama H, Takeuchi K (2006) Sustainability Science: building a new discipline. Sustainability Science 1: 1-6

Lasanta T, Arnáez J, Pascual N, Ruiz-Flaño P, Errea MP, Lana-Renault N (2017) Space-time process and drivers of land abandonment in Europe. Catena 149:810-823

Lang DJ, Wiek A, Bergmann M, Stauffacher $M$, Martens $P$, Moll $P, \ldots$ Thomas CJ (2012) Transdisciplinary research in sustainability science: practice, principles, and challenges. Sustainability science 7(1):25-43

Lefeuvre JC (2004) Plantes envahissantes, attention aux belles étrangères. Espaces naturels 5:11-13

Lévêque C, Tabacchi E, Menozzi MJ (2012) Les espèces exotiques envahissantes, pour une remise en cause des paradigmes écologiques. Sciences Eaux et Territoires, 6(1):2-9

Maire E, Marais-Sicre C, Guillerme S, Rhoné F, Dejoux JF, Dedieu G (2012) Télédétection de la trame verte arborée en haute résolution par morphologie mathématique comme aide à l'acceptabilité locale des politiques publiques environnementales. Revue Internationale de Géomatique, $\mathrm{n}^{\circ}$ spécial " Méthodes et outils en géomatique pour la cartographie de la Trame Verte et Bleue » 22(4):519-538

Marbuah G, Gren IM, McKie B (2014) Economics of Harmful Invasive Species: A Review. Diversity 6:500-523

Martin FM, Müllerová J, Borgniet L, Dommanget F, Breton V, Evette A (2018) Using single-and multi-date UAV and satellite imagery to accurately monitor invasive knotweed species. Remote Sensing, 10(10):1662 https://doi.org/10.3390/rs10101662

McAdam JH, Burgess PJ, Graves AR, Rigueiro-Rodríguez A, Mosquera-Losada MR (2009) Classifications and functions of agroforestry systems in Europe. In: Agroforestry in Europe, Springer, Dordrecht, pp 21-41

McCary MA, Mores R, Farfan MA, Wise DH (2016) Invasive plants have different effects on trophic structure of green and brown food webs in terrestrial ecosystems: a meta-analysis. Ecology Letters, 19(3):328-335

MacDougall AS, Turkington R (2005) Are invasive species the drivers or passengers of change in degraded ecosystems? Ecology 86(1):42-55

Michez A, Piégay H, Lisein J, Claessens H, Lejeune P (2016) Mapping of riparian invasive species with supervised classification of Unmanned Aerial System (UAS) imagery. International Journal of Applied Earth Observation and Geoinformation, 44:88-94

Moser WK, Barnard EL, Billings RF, Crocker SJ, Dix ME, Gray AN, et al. (2009) Impacts of nonnative invasive species on US forests and recommendations for policy and management. J. For., 107:320-327

Munroe DK, van Berkel DB, Verburg PH, Olson JL (2013) Alternative trajectories of land abandonment: causes, consequences and research challenges. Current Opinion in Environmental Sustainability, 5(5):471-476

Nerlich K, Graeff-Hönninger S, Claupein W (2013) Agroforestry in Europe: a review of the disappearance of traditional systems and development of modern agroforestry practices, with emphasis on experiences in Germany. Agroforestry Systems 87:475-492 
Paini DR, Sheppard AW, Cook DC, De Barro PJ, Worner SP, Thomas MB (2016) Global threat to agriculture from invasive species. Proceedings of the National Academy of Sciences, 113(27):7575-7579

Pándi I, Penksza K, Botta-Dukát Z, Kröel-Dulay G (2014) People move but cultivated plants stay: abandoned farmsteads support the persistence and spread of alien plants. Biodiversity and conservation, 23(5):1289-1302

Pepin KM, Wolfson DW, Miller RS, Tabak MA, Snow NP, Ver Cauteren KC, Davis AJ (2019) Accounting for heterogeneous invasion rates reveals management impacts on the spatial expansion of an invasive species. Ecosphere, 10(3):e02657. 10.1002/ecs2.2657

Perrings C, Williamson M, Barbier EB, Delfino D, Dalmazzone S, Shogren J, ... Watkinson A (2002) Biological invasion risks and the public good: an economic perspective. Conservation Ecology, 6(1)

Powell KI, Chase JM, Knight TM (2011) A synthesis of plant invasion effects on biodiversity across spatial scales. Am J Bot 98(3):539-548

Pysek P (2017) Current trends in plant invasion research. In: Máguas C, Crous C, Costa C (ed) EMAPI 14, International Conference on Ecology and Management of alien plant invasions, Lisboa, p.32

Ramos NC, Gastauer M, de Almeida Campos Cordeiro A et al. (2015) Environmental filtering of agroforestry systems reduces the risk of biological invasion. Agroforest Syst, 89:279-289. https://doi.org/10.1007/s10457-014-9765-7

Rejmánek M, Pitcairn MJ (2002) When is eradication of exotic pest plants a realistic goal? in Veitch C.R. and Clout M.N. (eds) Turning the tide: the eradication of invasive species. IUCN SSC Invasive Species Specialist Group. IUCN, Gland, Switzerland and Cambridge, UK, pp 249-253

Richardson DM, Rejmánek M (2011) Trees and shrubs as invasive alien species - a global review. Diversity \& Distributions, 17(5):788-809

Richardson AJ, Weigand CL (1977) Distinguishing vegetation from soil background information. Photogrammetric Engineering and Remote Sensing 43(12):15411552

Rigueiro-Rodríguez A, Fernández-Núñez E, González-Hernández P, McAdam JH, Mosquera-Losada MR (2009) Agroforestry systems in Europe: productive, ecological and social perspectives. In: Agroforestry in Europe, Springer, Dordrecht, pp 43-65

Savoie-Zajc L (2009) L'entrevue semi-dirigée. Dans Recherche Sociale: De la Problématique à la Collecte des Données. Montréal: Presses de l'Université du Québec: 337-360

Shackleton RT, Shackleton CM, Kull CA (2019) The role of invasive alien species in shaping local livelihoods and human well-being: A review. Journal of Environmental Management, 229:145-157

Simberloff D (2003) Confronting introduced species: a form of xenophobia?. Biological invasions 5(3):179-192

Simberloff D, Martin JL, Genovesi P, Maris V, Wardle DA, Aronson J, Courchamp F, Galil B, Garcia-Berthou E, Pascal M, Pysek P, Sousa R, Tabacchi E, Vila M (2013) Impacts of biological invasions: what's what and the way forwards. Trends in Ecology and Evolution 28(1):58-66

Simberloff D, Rejmánek M (Eds.) (2011) Encyclopedia of biological invasions (No. 3). Univ of California Press. 
Soudière (de la) M (2019) Arpenter le paysage. Poètes, géographes et montagnards. Anamosa, 383p.

Tanner RA, Gange AC (2013) The impact of two non-native plant species on native flora performance: potential implications for habitat restoration. Plant Ecol doi: $10.1007 / \mathrm{s} 11258-013-0179-9$

Tassin J (2020) Espèces invasives/envahissantes. in Dictionnaire Critique de I'Anthropocène, Editions du CNRS

Tilley C, Cameron-Daum K (2017) Anthropology of landscape. The extraordinary in the ordinary, London, UCL Press, 325p.

Trucker CJ (1979) Red and photographic infrared linear combinations for monitoring vegetation, Remote Sensing of the Environment 8:127-150

Udawatta PR, Rankoth L, Jose S (2019) Agroforestry and biodiversity. Sustainability, 11(10):2879

Van der Zanden EH, Verburg PH, Schulp CJ, Verkerk PJ (2017) Trade-offs of European agricultural abandonment. Land use policy 62:290-301

Vinogradovs I, Nikodemus O, Elferts D, Brūmelis G (2018) Assessment of sitespecific drivers of farmland abandonment in mosaic-type landscapes: A case study in Vidzeme, Latvia. Agriculture, Ecosystems \& Environment 253:113-121

Vítková MJ, Müllerová J, Sádlo J, Pergl, Pyšek P (2017) Black locust (Robinia pseudoacacia) beloved and despised: A story of an invasive tree in Central Europe. Forest Ecology and Management 384: 287-302.

Wallace CSA, Walker JJ, Skirvin SM, Patrick-Birdwell C, Weltzin JF, Raichle H (2016) Mapping Presence and Predicting Phenological Status of Invasive Buffelgrass in Southern Arizona Using MODIS, Climate and Citizen Science Observation Data. Remote Sens., 8:524

West AM, Evangelista PH, Jarnevich CS, Kumar S, Swallow A, Luizza MW, Chignell SM (2017) Using multi-date satellite imagery to monitor invasive grass species distribution in post-wildfire landscapes: An iterative, adaptable approach that employs open-source data and software. Int. J. Appl. Earth Obs. Geoinf., 59:135146 